\title{
NON-SYNCHRONISED MEIOSIS IN BINUCLEATE POLLEN MOTHER CELLS OF AN AVENA HYBRID
}

\author{
J. W. H. HOLDEN \\ Welsh Plant Breeding Station, Aberystwyth \\ and \\ MIGUEL MOTA \\ Estação de Melharamento de Plantas, Elvas, Portugal
}

Received 4.vii.55

\section{INTRODUCTION}

Villax and Mota (1953) treated a Triticum-Secale $\mathrm{F}_{1}$ hybrid with colchicine solution and found in the progeny plants with 42 chromosomes instead of $5^{6}$ as expected. These plants resembled the wheat parent and the " knob" appendages characteristic of rye chromosomes at pachytene were missing. They therefore believed that the rye chromosomes had been lost at the same time that the wheat chromosomes had been doubled through the action of colchicine.

During the summer of 1953 an $F_{1}$ plant with the somatic chromosome number of $2 n=2 \mathrm{I}$, derived from a cross between Avena barbata $(2 n=28)$ and Avena strigosa ssp. hirtula $(2 n=14)$, was injected with $\mathrm{o} \cdot \mathrm{I}$ per cent. aqueous colchicine solution at a stage when meiosis was imminent in the pollen mother cells. The injection was made into the elongating flowering culms. The aim was to repeat the process of differential genome elimination which had been postulated by Villax and Mota (loc. cit.).

A study of meiosis in the Avena hybrid was undertaken on pollen mother cells stained in aceto-carmine after fixation and storage in Carnoy (Darlington and La Cour, 1947) with added ferric chloride.

\section{CYTOLOGICAL OBSERVATIONS}

A study of meiosis revealed that the effect reported for the TriticumSecale hybrid had not been reproduced, and that the great majority of pollen mother cells showed a chromosome complement and meiotic behaviour normal for this hybrid.

Another abnormality was found, however, in the occurrence of a small proportion of binucleate pollen mother cells. In order to ascertain if this aberration was due to the colchicine treatment, an untreated hybrid of the same parentage was studied. This plant showed the same abnormality, and the data presented in this paper have been derived from it.

\section{(i) Cells}

Of 27 anthers examined, 23 were found to contain binucleate pollen mother cells, ranging in number from $\mathrm{I}$ to 9 per anther, and with a mean frequency of $\mathrm{I} \cdot 2$ per cent. of the total pollen mother cells 
examined (table $\mathrm{I}$ ). In the preparations these cells were frequently found to be associated in a group, indicating an origin in the same

TABLE I

Frequencies of binucleate P.M.Cs. in anthers which contain them compared with frequencies of uninucleate P.M.Cs. at various stages of meiosis

\begin{tabular}{|c|c|c|c|c|c|c|c|c|c|c|c|}
\hline & & \multicolumn{8}{|c|}{ Stage of division } & \multicolumn{2}{|c|}{ Total cells } \\
\hline $\begin{array}{c}\text { Slide } \\
\text { no. }\end{array}$ & $\begin{array}{l}\text { Cell } \\
\text { type }\end{array}$ & $\begin{array}{c}\text { Early } \\
\text { prophase }\end{array}$ & Diakinesis & MI & AI & Int. & MII & AII & TII & UN & BN \\
\hline 18 & $\begin{array}{l}\mathrm{UN}^{*} \\
\mathrm{BN}(\mathrm{C}) \dagger\end{array}$ & $\begin{array}{r}224 \\
4\end{array}$ & $\cdots$ & $\begin{array}{l}\ldots \\
\ldots\end{array}$ & $\begin{array}{l}\cdots \\
\cdots\end{array}$ & $\begin{array}{l}\ldots \\
\ldots\end{array}$ & $\ldots$ & $\begin{array}{l}\ldots \\
\ldots\end{array}$ & $\begin{array}{l}\cdots \\
\ldots\end{array}$ & 224 & 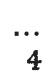 \\
\hline 19 & $\begin{array}{l}\text { UN } \\
\text { BN (C) }\end{array}$ & $\begin{array}{r}247 \\
8\end{array}$ & $\begin{array}{l}\cdots \\
\cdots\end{array}$ & $\ldots$ & $\ldots$ & $\begin{array}{l}\ldots \\
\ldots\end{array}$ & $\begin{array}{l}\cdots \\
\cdots\end{array}$ & $\begin{array}{l}\ldots \\
\ldots\end{array}$ & $\begin{array}{l}\ldots \\
\cdots\end{array}$ & 247 & 8 \\
\hline 21 & $\begin{array}{l}\text { UN } \\
\text { BN (C) }\end{array}$ & $\begin{array}{r}135 \\
3\end{array}$ & $\begin{array}{l}\cdots \\
\cdots\end{array}$ & $\begin{array}{l}\ldots \\
\ldots\end{array}$ & $\begin{array}{l}\ldots \\
\cdots\end{array}$ & $\begin{array}{l}\ldots \\
\ldots\end{array}$ & $\begin{array}{l}\cdots \\
\cdots\end{array}$ & $\begin{array}{l}\cdots \\
\cdots\end{array}$ & $\begin{array}{l}\ldots \\
\ldots\end{array}$ & 135 & $\begin{array}{r}\ldots \\
3\end{array}$ \\
\hline 24 & $\begin{array}{l}\text { UN } \\
\text { BN (C) }\end{array}$ & $\begin{array}{l}\ldots \\
\cdots\end{array}$ & $\begin{array}{r}257 \\
3\end{array}$ & $\begin{array}{r}15^{\circ} \\
2\end{array}$ & $\begin{array}{l}\ldots \\
\cdots\end{array}$ & $\begin{array}{l}\ldots \\
\cdots\end{array}$ & $\begin{array}{l}\cdots \\
\cdots\end{array}$ & $\begin{array}{l}\ldots \\
\ldots\end{array}$ & $\begin{array}{l}\cdots \\
\cdots\end{array}$ & 407 & $\ldots$ \\
\hline 17 & $\begin{array}{l}\text { UN } \\
\text { BN (C) }\end{array}$ & $\cdots$ & $\begin{array}{c}282 \\
\ldots\end{array}$ & $\begin{array}{l}55 \\
\cdots\end{array}$ & $\begin{array}{l}I I \\
\cdots\end{array}$ & $\begin{array}{l}22 \\
\cdots\end{array}$ & $\begin{array}{l}\cdots \\
\cdots\end{array}$ & $\begin{array}{l}\cdots \\
\cdots\end{array}$ & $\begin{array}{l}\cdots \\
\cdots\end{array}$ & $37^{\circ}$ & $\begin{array}{r}\ldots \\
9\end{array}$ \\
\hline $\mathbf{r}$ & $\begin{array}{l}\text { UN } \\
\text { BN (C) }\end{array}$ & ${ }_{2}$ & $\begin{array}{l}\ldots \\
\cdots\end{array}$ & $\begin{array}{r}448 \\
3\end{array}$ & $\begin{array}{c}2 \\
\cdots\end{array}$ & $\begin{array}{l}\cdots \\
\cdots\end{array}$ & $\begin{array}{l}\cdots \\
\cdots\end{array}$ & $\begin{array}{l}\cdots \\
\cdots\end{array}$ & $\begin{array}{l}\ldots \\
\cdots\end{array}$ & $45^{\circ}$ & $\begin{array}{r}\ldots \\
5\end{array}$ \\
\hline 6 & $\begin{array}{l}\text { UN } \\
\text { BN (C) }\end{array}$ & $\begin{array}{l}\cdots \\
\cdots\end{array}$ & $\begin{array}{l}\ldots \\
\cdots\end{array}$ & $\begin{array}{r}514 \\
\mathrm{I}\end{array}$ & $\begin{array}{c}4 \\
\ldots\end{array}$ & $\begin{array}{l}13 \\
\cdots\end{array}$ & $\begin{array}{l}\cdots \\
\cdots\end{array}$ & $\begin{array}{l}\cdots \\
\cdots\end{array}$ & $\begin{array}{l}\ldots \\
\cdots\end{array}$ & $53^{I}$ & $\cdots$ \\
\hline 22 & $\begin{array}{l}\text { UN } \\
\text { BN (C) }\end{array}$ & $\begin{array}{l}\ldots \\
\cdots\end{array}$ & $\begin{array}{l}\ldots \\
\cdots\end{array}$ & $\begin{array}{r}470 \\
I\end{array}$ & $\ldots$ & $\begin{array}{l}\ldots \\
\cdots\end{array}$ & $\begin{array}{l}\ldots \\
\cdots\end{array}$ & $\ldots$ & $\begin{array}{l}\ldots \\
\cdots\end{array}$ & 470 & 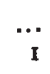 \\
\hline 26 & $\begin{array}{l}\text { UN } \\
\text { BN (C) }\end{array}$ & $\begin{array}{l}\cdots \\
\cdots\end{array}$ & $\begin{array}{l}\cdots \\
\cdots\end{array}$ & $\begin{array}{r}459 \\
7\end{array}$ & $\begin{array}{c}I \\
\ldots\end{array}$ & $\begin{array}{l}\cdots \\
\cdots\end{array}$ & $\begin{array}{l}\ldots \\
\cdots\end{array}$ & $\begin{array}{l}\cdots \\
\cdots\end{array}$ & $\begin{array}{l}\cdots \\
\cdots\end{array}$ & 460 & 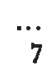 \\
\hline 25 & $\begin{array}{l}\text { UN } \\
\text { BN (C) }\end{array}$ & $\ldots$ & $\begin{array}{l}\ldots \\
\ldots\end{array}$ & $\begin{array}{r}243 \\
2\end{array}$ & $\begin{array}{l}8 \\
1\end{array}$ & $\begin{array}{l}8 \\
\text { I }\end{array}$ & $\begin{array}{l}\ldots \\
\ldots\end{array}$ & $\begin{array}{l}\ldots \\
\ldots\end{array}$ & $\begin{array}{l}\ldots \\
\ldots\end{array}$ & 259 & 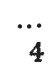 \\
\hline 27 & $\begin{array}{l}\text { UN } \\
\text { BN (C) }\end{array}$ & $\begin{array}{l}\ldots \\
\ldots\end{array}$ & $\ldots$ & $\begin{array}{r}196 \\
3\end{array}$ & $\begin{array}{l}23 \\
\ldots\end{array}$ & $\begin{array}{c}G \\
\cdots\end{array}$ & $\begin{array}{l}\ldots \\
\cdots\end{array}$ & $\ldots$ & $\begin{array}{l}\ldots \\
\ldots\end{array}$ & 225 & $\begin{array}{r}\ldots \\
3\end{array}$ \\
\hline 23 & $\begin{array}{l}\text { UN } \\
\text { BN (C) }\end{array}$ & $\begin{array}{l}\ldots \\
\cdots\end{array}$ & $\begin{array}{l}\ldots \\
\cdots\end{array}$ & $\begin{array}{r}198 \\
2\end{array}$ & $\begin{array}{l}16 \\
\ldots\end{array}$ & $\begin{array}{l}I 17 \\
\ldots\end{array}$ & $\begin{array}{l}\ldots \\
\cdots\end{array}$ & $\begin{array}{l}\ldots \\
\cdots\end{array}$ & $\begin{array}{l}\ldots \\
\cdots\end{array}$ & $33^{x}$ & $\underset{2}{2}$ \\
\hline 14 & $\begin{array}{l}\mathrm{UN} \\
\mathrm{BN}(\mathrm{C})\end{array}$ & $\begin{array}{l}\cdots \\
\cdots\end{array}$ & $\ldots$ & $\begin{array}{r}39 \\
3\end{array}$ & $\begin{array}{l}7 \\
1\end{array}$ & $\begin{array}{c}297 \\
\ldots\end{array}$ & $\begin{array}{l}55 \\
\cdots\end{array}$ & $\begin{array}{l}\ldots \\
\cdots\end{array}$ & $\begin{array}{l}\ldots \\
\cdots\end{array}$ & $39^{8}$ & $\begin{array}{r}\ldots \\
4\end{array}$ \\
\hline I6 & $\begin{array}{l}\text { UN } \\
\text { BN (C) }\end{array}$ & $\begin{array}{l}\ldots \\
\cdots\end{array}$ & $\begin{array}{l}\ldots \\
\cdots\end{array}$ & ${ }_{\text {I }}$ & $\stackrel{.}{\mathrm{I}}$ & $\begin{array}{r}182 \\
2\end{array}$ & $\begin{array}{l}I 2 \\
\cdots\end{array}$ & $\begin{array}{c}3 \\
\ldots\end{array}$ & $\begin{array}{c}37^{2} \\
\cdots\end{array}$ & $5^{69}$ & $\begin{array}{r}\ldots \\
4\end{array}$ \\
\hline & & & & & & & & & & $5^{\circ} 7^{6}$ & 60 \\
\hline
\end{tabular}

* UN $=$ Uninucleate. $\quad \dagger \mathrm{BN}(\mathrm{C})=$ Central nucleus of binucleate cell.

Note.-All peripheral nuclei in all slides are in early prophase.

part of the anther loculus. The binucleate cells were frequently somewhat retarded in their stage of division in relation to the normal cells of the same anther, and their lagging was more marked as the normal cells approached completion of meiosis (table r). Onset of 
prophase appeared to be synchronous in the two types of cell. No cells with more than one nucleus were seen at the second division.

\section{(ii) Nuclei}

In the binucleate cells the nuclei were disposed, one in a central or sub-central position, the other in a sub-central or peripheral position (plate, figs. $\mathrm{I}-4$; and fig. $\mathrm{I}$ ).

Both nuclei appear to commence prophase together (plate, fig. I) but a lack of synchronisation soon becomes apparent. As the central nucleus proceeds through its stages, the lagging of the peripheral

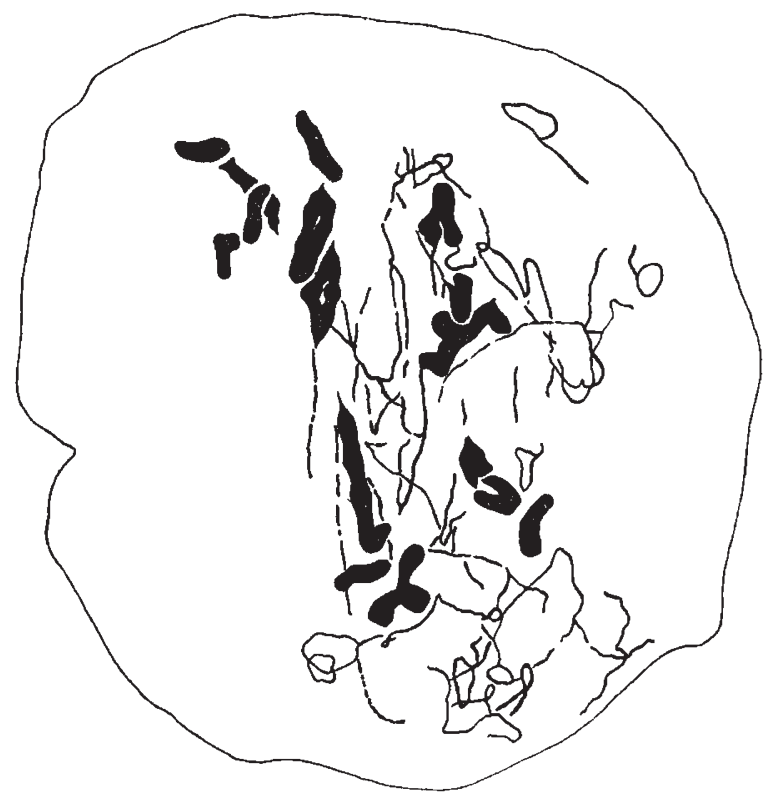

Fig. 1.-Binucleate pollen mother cell. Note lack of synchronisation in the division of the two nuclei, and the general condition of their chromosomes. Central nucleus at

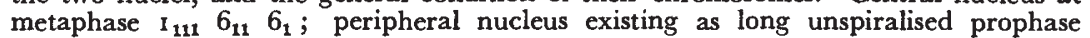
threads. $\times 800$.

nucleus becomes very marked (plate, figs. 2-4 and table r) and it does not progress beyond an early prophase condition (plate, fig. 4).

The central nucleus was seen in favourable preparations of metaphase to be triploid $(2 n=2 \mathrm{I}$ ) (fig. I), indicating that the peripheral nucleus was not merely a part removed from the normal complement. In the majority of cells, however, chromosomes of the central nucleus were clumped together (plate, fig. 2) and frequently had a "sticky" appearance. There was no evidence of failure of separation at anaphase and apart from these two disturbances to metaphase, the central nuclei behaved and completed their first division in a normal manner.

The peripheral nuclei, on the other hand, showed a highly pathological appearance. Plate figs. $1-4$, show some of them in association with central nuclei at various stages of the first meiotic 
division. At early prophase (plate, fig. I) the peripheral possesses no recognisable nucleolus, while that in the central nucleus is well developed. They are also characterised by reduced staining capacity, poor spiralisation and fragmentation of their chromosomes. The degree of expression of these latter abnormalities varies from cell to cell, ranging from long, extremely thin, poorly stained threads (plate, fig. 2) to nuclei where the chromosomes showed contraction, improved staining and extreme fragmentation. In occasional nuclei these contracted fragments were seen to be paired, and while this may be attributed to the zygotene pairing of homologous chromosome fragments, it is more probably the result of reproduction. Occasional small ring formations are interpreted as the result of reunion of fragments. The determination of the number of chromosomes in these nuclei was impossible. It is clear that the fragments will disappear into the cytoplasm of the pollen mother cell or its daughters. One cell was seen where the central daughter nuclei had reached first telophase and where the peripheral fragments were being divided into two groups by the new cell wall.

\section{DISCUSSION}

There are a number of reports in the literature of the occurrence of binucleate pollen mother cells. These reports are classified in table 2 according to the phenotypic similarity of the two nuclei and to their genotypic relationship so far as this can be determined.

In only two cases is there any parallel to the marked phenotypic differences found between the nuclei in our material.

Rees (1955) found binucleate pollen mother cells in inbred rye. There, the extra nuclei vary in their chromosome number from one acentric fragment to a complete diploid complement. He attributes their presence to two different causes, both operating at pre-meiotic mitosis, (i) the micronuclei to spindle errors and (ii) the complete nuclei to failure of cell wall formation.

Kihara and Lilienfeld (I934) report binucleate pollen mother cells in a $T$. aegilopoides - Ae. squarrosa hybrid. They attribute the binucleate condition to the migration of metaphase chromosomes or of whole or parts of nuclei when in meiotic prophase. They find a variation in the behaviour of the "migrant" nuclei. Those existing as long poorly staining threads, or bundles of threads, eventually degenerate, and are resorbed into the cytoplasm. These nuclei they suppose have migrated while in the prophase condition. In others, the "migrant" nucleus exists as normally spiralised metaphase chromosomes which are thought to have migrated in that condition, or as entire prophase nuclei which have come to lie in contact with the legitimate nucleus, and have subsequently developed in a normal manner. No indication of chromosomal or nuclear migration has been seen in our material, and another explanation of the origin of the binucleate condition will be advanced later. However, this 
suggestion of a relationship between nuclear behaviour and position in the cell is similar to that found by us.

A notable feature of the peripheral nuclei is their lack of a nucleolus. The point arises whether they are complete nuclei, or micronuclei deficient in nucleolar organisers. In the latter event their lack of nucleoli and subsequent degeneration could be attributed to their genetic deficiency. This explanation of their differentiation must be

TABLE 2

Classification of reported cases of binucleate pollen mother cells according to genetic similarity and phenotypic behaviour of the nuclei

\begin{tabular}{|c|c|c|c|}
\hline \multicolumn{4}{|c|}{ GENOTYPE } \\
\hline \multirow{3}{*}{ 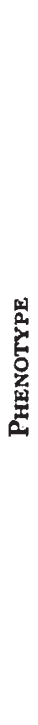 } & & Presumed identical & Known to be different \\
\hline & 氶 & 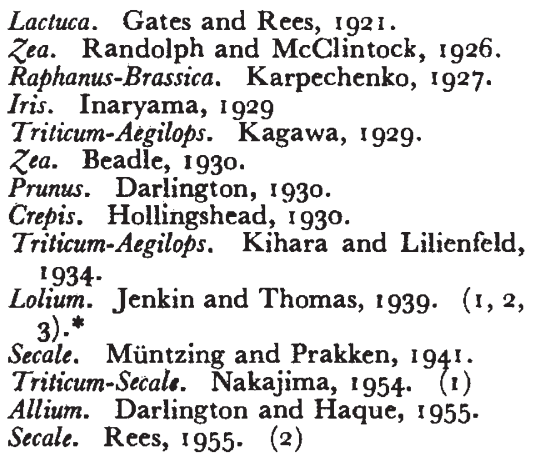 & $\begin{array}{l}\text { Triticum-Aegilops. Kihara and } \\
\text { Lilienfeld, I } 934 . \\
\text { Pyrus. Crane and Thomas, } 1939 .\end{array}$ \\
\hline & 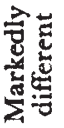 & $\begin{array}{l}\text { Triticum-Aegilops. Kihara and Lilienfeld, } \\
\text { ' } 934 . \\
\text { Avena. H. and M. }\end{array}$ & Secale. Rees, I 955. \\
\hline
\end{tabular}

* เ. Imperfect synchronisation.

2. Reduced spiralisation of one chromosome complement.

3. Some asynapsis in one nucleus.

rejected, however, since all the peripheral nuclei lack a nucleolus and therefore it would entail the operation at pre-meiotic mitosis of a mechanism for the production of regular genetic differences between sister nuclei.

Since it has been possible in a few cells to determine that the central nucleus consists of the full triploid complement, we make the assumption that the peripheral nucleus is present as a result of failure of cell wall formation at pre-meiotic mitosis.

When two nuclei are present in a common cytoplasm it is possible that competition would occur between them during prophase for the materials necessary for chromosome synthesis. If the proposed mode of origin of the binucleate cells is correct, competitive advantage (in a genetic sense) cannot be postulated as the prime cause of the 
difference in behaviour of the two nuclei, for they are genetically identical. The prime cause must therefore lie outside the nucleus and in the cytoplasm.

This view is supported by the second notable feature of these cells, that is, the consistent relationship between position and behaviour of the nuclei. As already described, the degenerate nuclei are farther from the cell centre than the normal nuclei. In fact they are usually peripheral.

Koller (1947) referring to the synchronisation of meiosis or mitosis in binucleate or multi-nucleate cells makes the point that the simultaneous division of several independent nuclei can only be understood by assuming a distribution throughout the cell of the substance, or its precursors, necessary for chromosome synthesis. $\mathrm{He}$ also suggests that the demands of the individual nuclei guarantee a stable equilibrium in the even distribution of the product of the "centres of synthesis". While this may well be true, it cannot apply in all cases.

Cytoplasmic differentiation has been shown by La Cour (1949) to be closely associated with nuclear differentiation in form and function in pollen grains of Scilla sibirica and Luzula purpurea. The behaviour of the nuclei in the Scilla tetrad, with the generative nuclei arranged at the apices of the inner walls, and the vegetative nuclei in a peripheral position, bears a close resemblance to the orientation of the nuclei in our material (see fig. 2). The Luzula pollen mother cell (La Cour, loc. cit.) illustrates an intermediate developmental stage between the binucleate Avena pollen mother cell and the differentiated tetrad as in Scilla, and shows with its differentiated nuclei but undivided cytoplasm an even more remarkable similarity to the phenomenon described here. In Luzula the four deeply staining generative nuclei lie in a central position, with the vegetative nuclei towards the periphery. Darlington and Mather (1949) infer from the Scilla tetrad that the concentration of "generative-nucleus-forming substances" is central in the pollen mother cell. The differences described here between the two nuclei in the Avena pollen mother cell support this view, since the function of the generative nucleus on the one hand, and the central pollen mother cell nucleus on the other, is to divide again, and, whatever factors are necessary for the division of the former, are likely to be necessary for the division of the latter also.

It is suggested, therefore, that a cytoplasmic gradient is responsible for the difference between the two nuclei of the pollen mother cell, just as it is responsible for the differentiation of the pollen grain three cell-generations later. While the gradient in the two types of cell may be in respect of different factors, both operating to produce a similar effect on nuclear behaviour, it is also possible that the factors may be identical. Mather (1948) has shown how the nuclear genotype may alter the nuclear phenotype through the medium of the cytoplasm and has pointed out the lag in time that frequently occurs between 
the presence of a nucleus in the cytoplasm and its effect on itself or a subsequent nucleus in a later cell generation. In the case of the binucleate cells described, we may have an example of an exceptionally early effect of the normal pollen grain differentiation process, brought on by the abnormal binucleate condition.

Fig. $2(d)$ shows the spatial relationships of the differentiated areas of cytoplasm in the tetrad of Scilla (after La Cour, I949) and their probable relationship to those postulated for the pollen mother cell, $2(a)$.

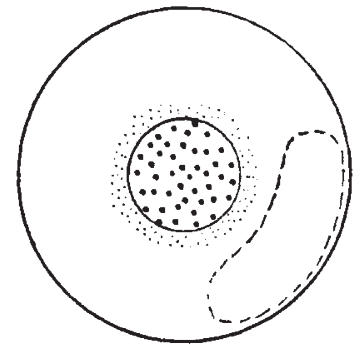

a

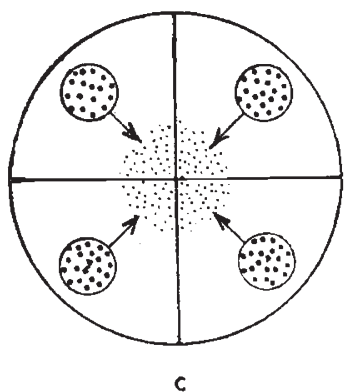

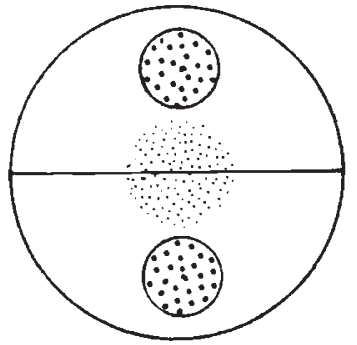

b

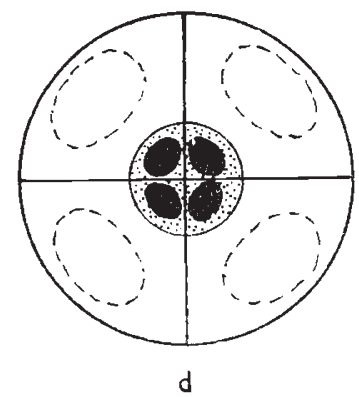

FIG. 2.-Relationship between cytoplasmic differentiation in pollen grain (d) (adapted from La Cour, 1949) and that postulated for tetrad (c), dyad $(b)$ and pollen mother cell $(a)$.

Degenerate nuclei : broken line.

Generative nuclei : black.

Concentration of " generative-nucleus-forming substance" : stippled.

Arrows in $(c)$ indicate direction of gradient and direction of migration of tetrad nuclei.

According to Sax and Husted (1936) the primary microspore nucleus at the time of its division lies near the inner wall, while they and Geitler (1935) have shown that in a large majority of species the generative nucleus also lies in this position. The fact that the primary nucleus migrates to this position and organises its chromosomes and spindle eccentrically within the cell is strong indication that the differentiation gradient retains the same orientation as that in the pollen mother cell, despite two intervening nuclear and cell divisions.

There remains the apparent inconsistency of the dyad nuclei, which divide in a position remote from the focus of the gradient, where they might be expected to suffer the same degeneration as 
the vegetative nucleus of the pollen grain and the peripheral nucleus of the pollen mother cell. However, two factors are worth consideration in this connection, namely ( $I$ ) the haploid nucleus of the dyad consists of chromosomes which have already divided and which bring into the nucleus their own charge of chromatin material, and (ii) the interphase stage of this nucleus is usually very short and its need for physiologic activity, apart from the reproduction of the centromeres, would therefore seem to be nil. Thus as a result of its special internal self sufficiency it is independent of the cytoplasmic gradient.

Since we have no reason to suppose that the peripheral nucleus lacks a nucleolar organiser, the absence of a nucleolus from this nucleus is revealing, for the nucleolar material is believed to be intimately associated with chromosome synthesis. It is possible that the forces operating to maintain the gradient with its focus at the cell centre have also been responsible for the transference of nucleolar material from the peripheral nucleus at the preceding telophase.

The differentiation of the nuclei in the binucleate pollen mother cells would therefore seem to be a premature function of the phenomenon which is later to differentiate the nuclei in the pollen grain.

\section{SUMMARY}

I. A small proportion of binucleate pollen mother cells was found in the $\mathrm{F}_{1}$ hybrid Avena barbata $\times A$. strigosa ssp. hirtula, $2 n=2 \mathrm{I}$.

2. A marked difference in the behaviour of the two nuclei at first meiotic division was found to be associated with their positions in the cell.

3. The central nucleus was essentially normal in behaviour; it was triploid.

4. The peripheral nucleus contained no nucleolus. Its chromosomes showed reduced staining capacity, poor spiralisation, and fragmentation. It degenerated and disappeared.

5. The binucleate condition is attributed to failure of cell wall formation at pre-meiotic mitosis and the two nuclei are therefore considered to be identical sisters.

6. Cytoplasmic gradients are supposed to determine differentiation of the genetically identical nuclei in the pollen grain. It is proposed that the same cause is responsible for the differentiation of the nuclei in these binucleate cells, for there is a marked similarity in their behaviour to that of the nuclei in the pollen grain.

Acknowledgments.-We wish to thank Professor E. T. Jones, Director of the Welsh Plant Breeding Station, Aberystwyth, for the opportunity and facilities provided to carry out this investigation. We are indebted to Professor P. T. Thomas, Department of Agricultural Botany, U.C.W., Aberystwyth, and to Mr L. F. La Cour, John Innes Horticultural Institution, Bayfordbury, for criticism and advice. Miguel Mota expresses thanks to the British Council for a bursary which enabled him to work in Great Britain for a short period in 1953 . 


\section{Plate}

Illustrating differentiation of nuclei in binucleate pollen mother cells of the hybrid A. barbata $\times$ A. strigosa ssp. hirtula $\mathrm{F}_{1}$. Aceto-carmine.

FIg. 1.-Early prophase. Nucleolus present in central nucleus and lacking in peripheral. $\times$ I roo.

Frg. 2.-Central nucleus at diakinesis, configurations clumped. Peripheral at early prophase and showing fragmentation. $\times 1300$.

Fig. 3.-Central nucleus at anaphase-telophase. Univalents dividing on plate. Extreme fragmentation of peripheral. $\times 1510$.

Frg. 4.-Central nucleus at telophase. Peripheral still in an early prophase condition and showing extreme fragmentation. $\times 880$. 


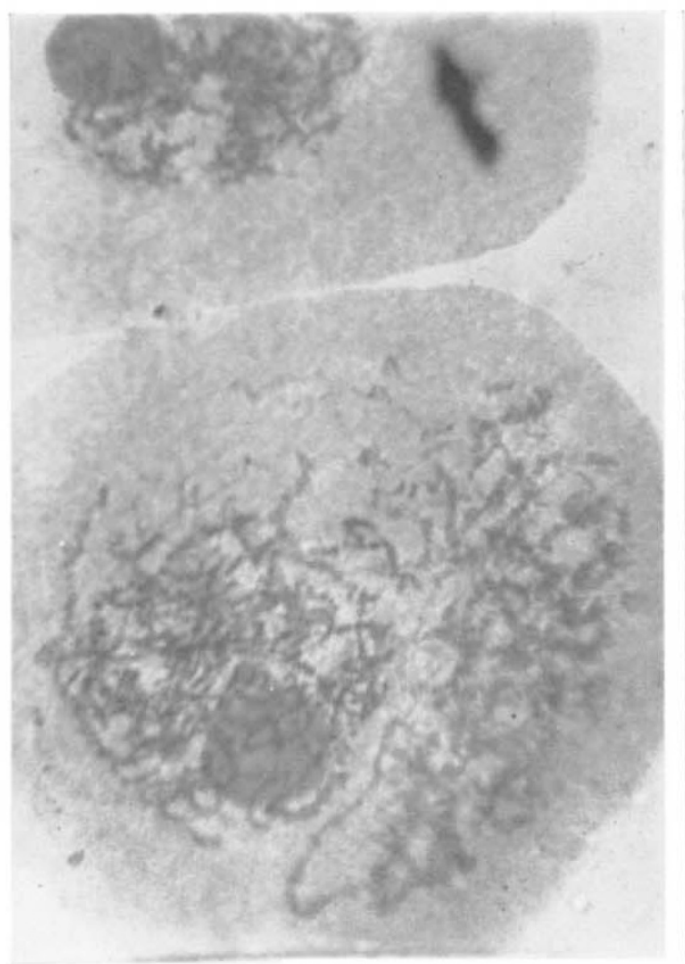

FIG. I.

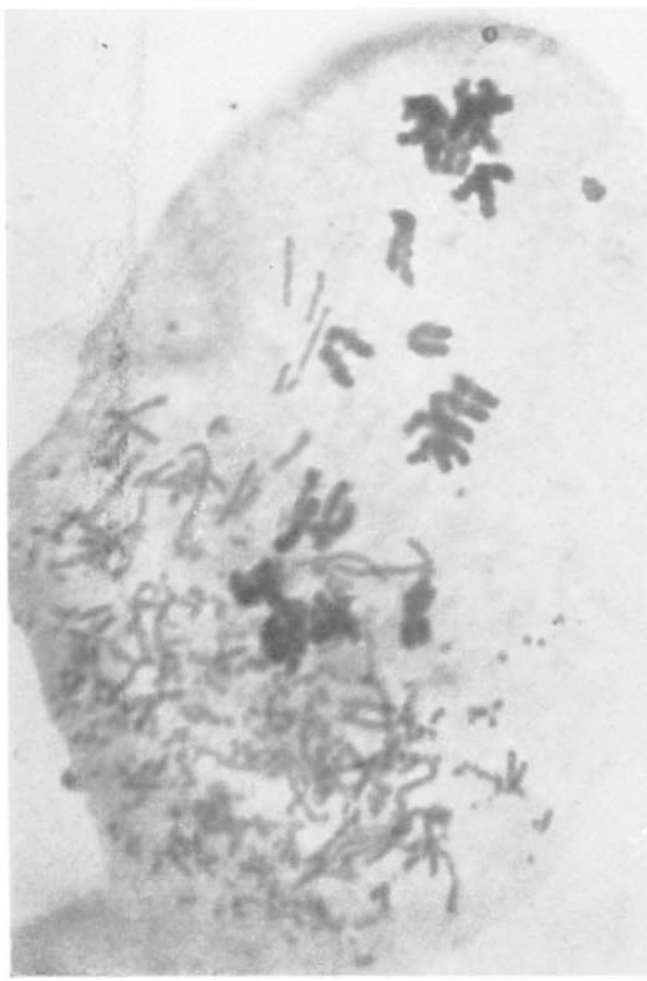

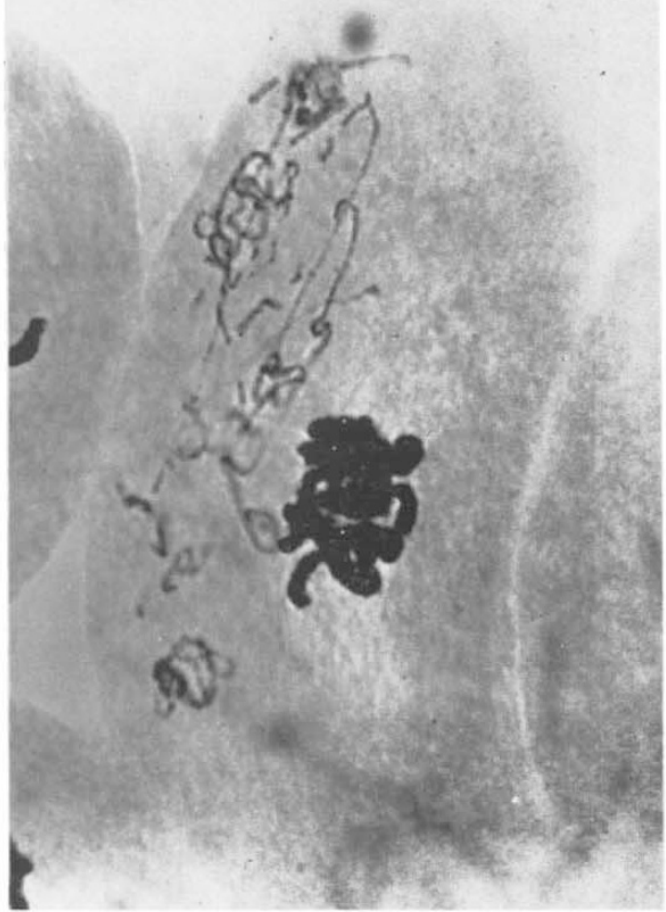

FIG. 2.

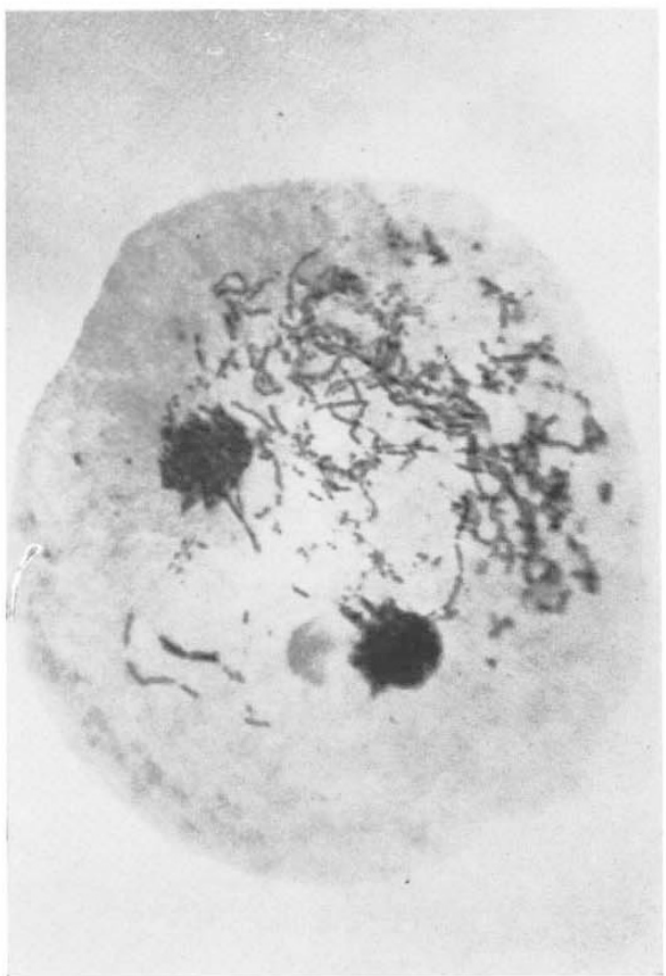

Fic. 3.

FIG. 4. 


\section{REFERENCES}

BEADLE, G. W. 1930. Genetical and cytological studies of Mendelian asynapsis in Zea mays. Gornell Univ. Agric. Experimental Station, Mem. 129.

CRANE, M. B., AND THOMAS, P. T. 1939. Genetical studies on pears. I. The origin and behaviour of a new giant form. F. Genet., 37 (2), 287-299.

Darlington, C. D. 1930. Studies in Prunus. III. F. Genet., 22, 65-93.

DARLINGton, C. D., AND LA COUR, L. F. 1947. The Handling of Chromosomes. London : George Allen and Unwin.

DARlington, c. D., AND MATHER, K. 1949. The Elements of Genetics. London : George Allen and Unwin.

DARLINGTON, C. D., AND HAQUE, A. 1955. The timing of mitosis and meiosis in Allium ascalonicum: A problem of differentiation. Heredity, 9 (1), I17-127.

GATES, R. R., AND REES, E. M. 1921. A cytological study of pollen development in Lactuca. Ann. Bot., Lond., 35, 365-398.

GEITLER, F. 1935. Beobachtungen über die este Teilung in Pollenkorn der Angiospermen. Planta, 24, 361-386.

hollingsheAd, L. 1930. A cytological study of haploid Crepis capillaris plants. Univ. Calif. Publ. agric. Sci., 6, 107-1 34 .

inaryama, s. 1929. Karyological studies of Iris Kaempferi, sieb. Fap. F. Bot., $4(4), 405-425$.

JENKIN, T. J., AND THOMAS, P. T. 1939. Interspecific and intergeneric hybrids in herbage grasses. III. Lolium loliacium and Lolium rigidium. F. Genet., 37, 255-286.

KAGAWA, F. 1929. Cytological studies on the pollen formation of the hybrids between Triticum and Aegilops. 7ap. F. Bot., 4 (4), 345-36r.

KARPECHENKo, G. D. 1927. The production of polyploid gametes in hybrids. Hereditas, 9, 349-368.

KIHARA, H., AND LILIENFELD, F. 1934. Kerneinwanderung und Bildung syndiploider Mutterzelleren bei dem $F_{1}$-Bastard Triticum aegilopoides $\times$ Aegilops squarrosa. Fap. F. Genet., io (1), 1-28.

KOLLER, P. C. 1947. The experimental modification of nucleic acid systems in the cell. Symposia of the Soc. Exp. Biol., No. 1, 270-290.

LA CoUR, L. F. 1949. Nuclear differentiation in the pollen grain. Heredity, 3 (3), 319-337.

MATHER, K. 1948. The nucleus and cytoplasm in differentiation. Symposia of the Soc. Exp. Biol., No. 2, 196-2 16.

MÜNTZING, A., AND PRAKKEN, R. 194I. Chromosomal aberrations in rye populations. Hereditas, $27,273-308$.

NaKajima, G. 1954. Genetical and cytological studies in the breeding of amphidiploid types between Triticum and Secale VIB. Meiosis of pollen mother cells of $T$. compactum $\times S$. cereale. $\quad F_{2}$ plants with $2 n=5^{6}$ and $5^{8}$ chromosomes. Fap. F. Breeding, 3 (3-4), 47-52, 53-58.

RANDOlph, L. F., AND MCCLINTOck, B. 1926. Polyploidy in Zea mays L. Amer. Nat., 6o, 99-102.

REES, H. 1955. Genotypic control of chromosome behaviour in rye. 1. Inbred lines. Heredity, 9 (I), 93-116.

SAX, K., AND hUSTED, L. 1936 . Polarity and differentiation in microspore development. Amer. F. Bot., 23, 6o6-6og.

villax, E., AND MOTA, M. 1953. Behaviour of a Triticum $\times$ Secale hybrid under the action of colchicine. Nature, $172,4^{12}$. 